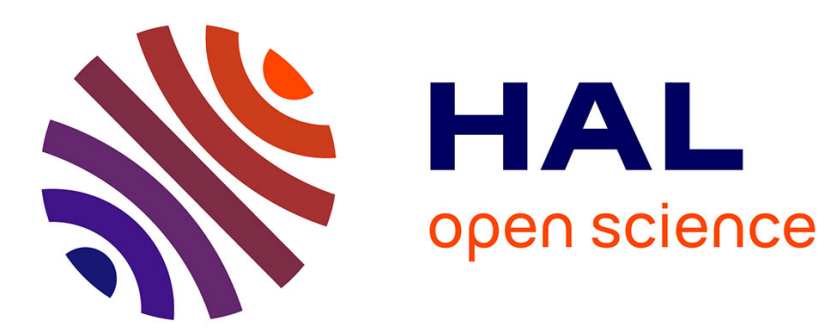

\title{
Herbicide occurrence in riparian soils and its transporting risk in the Songhua River Basin, China
}

Xiaoyin Sun, Qixing Zhou, Wenjie Ren

\section{To cite this version:}

Xiaoyin Sun, Qixing Zhou, Wenjie Ren. Herbicide occurrence in riparian soils and its transporting risk in the Songhua River Basin, China. Agronomy for Sustainable Development, 2013, 33 (4), pp.777-785. 10.1007/s13593-013-0154-9 . hal-01201401

\section{HAL Id: hal-01201401 \\ https://hal.science/hal-01201401}

Submitted on 17 Sep 2015

HAL is a multi-disciplinary open access archive for the deposit and dissemination of scientific research documents, whether they are published or not. The documents may come from teaching and research institutions in France or abroad, or from public or private research centers.
L'archive ouverte pluridisciplinaire HAL, est destinée au dépôt et à la diffusion de documents scientifiques de niveau recherche, publiés ou non, émanant des établissements d'enseignement et de recherche français ou étrangers, des laboratoires publics ou privés. 


\title{
Herbicide occurrence in riparian soils and its transporting risk in the Songhua River Basin, China
}

\author{
Xiaoyin Sun • Qixing Zhou • Wenjie Ren
}

Accepted: 22 April 2013 /Published online: 14 June 2013

(C) INRA and Springer-Verlag France 2013

\begin{abstract}
A riparian zone is the interface between land and a river or stream. Riparian zones are major elements of ecosystems. However, human conversion of riparian land to agricultural uses has reduced the ecological benefits of riparian land such as water and pollutant filtration. Over $80 \%$ of the original riparian area has been lost from North America and Europe over the past 200 years. Intensive land use along riparian areas has increased soil erosion and, in turn, sedimentation in rivers. Intensive land use has also increased the transfer of unused fertilizers, e.g., nitrates and pesticides in river water. We therefore studied pesticide transfer and soil erosion in riparian zones of the Songhua River Basin in China. For that, we identified land use type and measured herbicide residues of acetochlor and atrazine in riparian soils and soil columns of samples from 248 stations. We also modeled the risk of herbicide transfer. Our results show that herbicides were detected in $97 \%$ of the samples, evidencing a widespread contamination. Acetochlor residue concentrations in soils are $26.10 \mu \mathrm{g} / \mathrm{kg}$ for farm land, $1.76 \mu \mathrm{g} / \mathrm{kg}$ for grass land, $1.46 \mu \mathrm{g} / \mathrm{kg}$ for forest land, and $2.48 \mu \mathrm{g} / \mathrm{kg}$ for bare land on average. Atrazine residue concentrations in soils are $11.28 \mu \mathrm{g} / \mathrm{kg}$ for farm land, $0.51 \mu \mathrm{g} / \mathrm{kg}$ for grass land, not detected in forest land, and $0.13 \mu \mathrm{g} / \mathrm{kg}$ for bare
\end{abstract}

X. Sun

College of Geography and Tourism, Qufu Normal University,

Rizhao 276826, China

\section{Q. Zhou ( $₫)$}

Key Laboratory of Pollution Processes and Environmental Criteria (Ministry of Education), College of Environmental Science and Engineering, Nankai University, Tianjin 300071, China e-mail: Zhouqx523@126.com

\section{Sun $\cdot$ W. Ren}

Key Laboratory of Pollution Ecology and Environmental Engineering, Institute of Applied Ecology, Chinese Academy of Sciences, Shenyang 110016, China land on average. Atrazine residue concentration increased in riparian agricultural soils below $25 \mathrm{~cm}$; whereas atrazine residue concentration of grassland soils showed a decrease. We found also that the highest risk of soil erosion and herbicide transfer is located in the middle reach of the Songhua River.

Keywords Herbicide · Agricultural soil · Riparian zone · Transporting risk $\cdot$ River basin management

\section{Introduction}

Riparian zones, which are broadly defined as areas in the interface of the terrestrial and aquatic environment (Naiman and Décamps 1997), have become increasingly important elements of river basin management (Zhou 2005). Their boundaries extended outward to the limits of flooding and upward into the canopy of streamside vegetation (Zhao et al. 2009). In spite of small areas within a watershed, riparian zones often have a considerable influence on water quality and aquatic ecosystems of streams. However, human activities, especially conversion of riparian land to agricultural uses, have resulted in a degradation of ecological function on retention of pollutants and loss of riparian habitats (Tomer et al. 2009; Vidon et al. 2010) (Fig. 1).

Intensive land use along riparian areas may lead to increased soil erosion and sedimentation in rivers and increased inputs of nutrients and agricultural chemicals (Zhou and Luo 2011). Over $80 \%$ of the original riparian area has been lost from North America and Europe over the past 200 years (Naiman et al. 1993). In China, many parts of the riparian zones of rivers and streams have been destroyed seriously and widely (Huang et al. 2007); for example, some research indicated that the ratio of farmland and constructive land in riparian zones of the Yellow River delta increased greatly 
Fig. 1 Riparian maize farmland and discarded bottle of herbicide

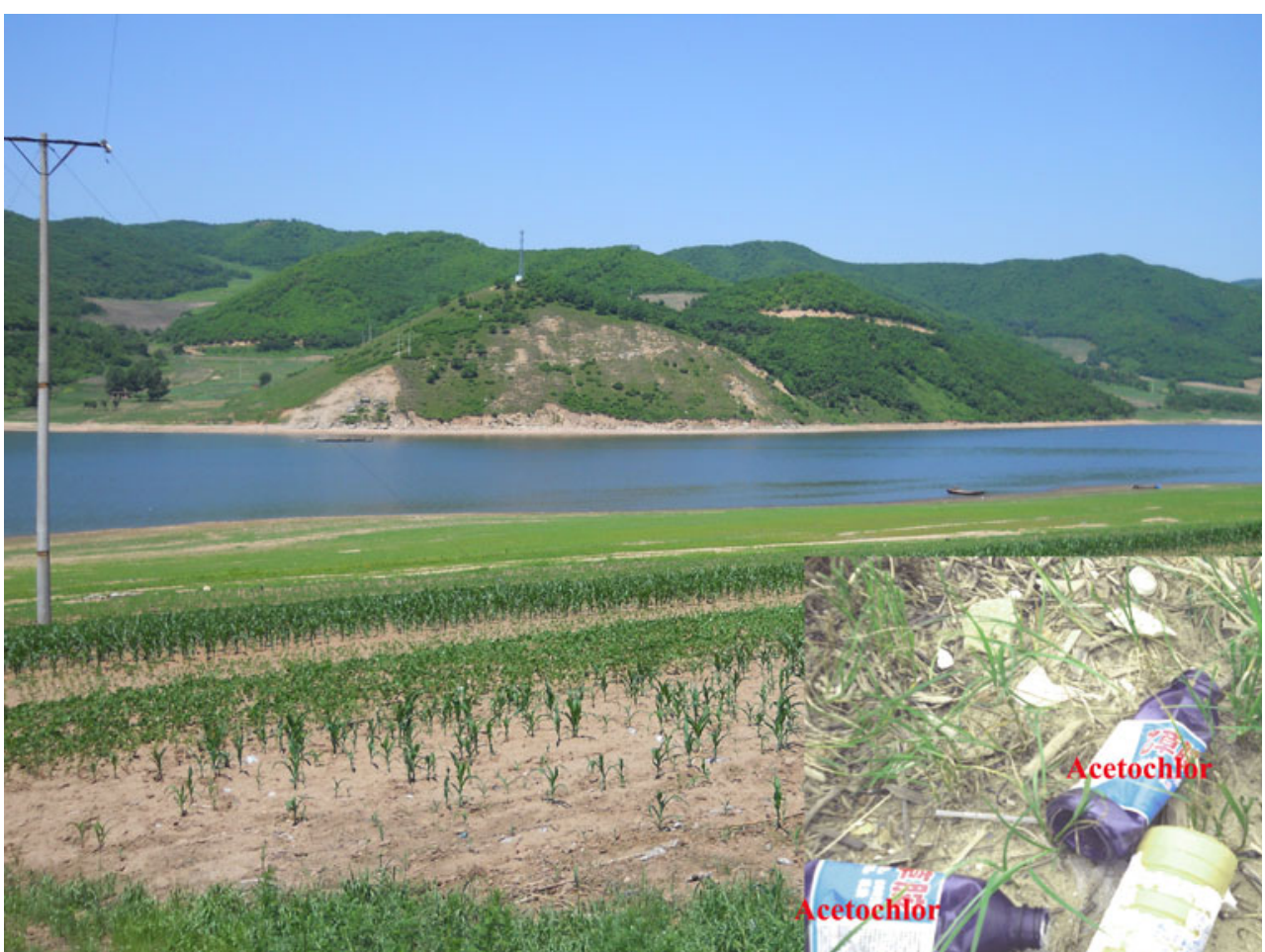

and the intensity levels of land use improved 18-23 times from the year 1986 to 2001 (Guo 2005). Despite degradation of riparian zones, few attempts have been made to assess the risk of riparian land use and stream water contamination, especially riparian agriculture and agrichemicals pollution.

Like a physical barrier, riparian buffer zones act to prevent transportation of sediments and solutes mainly in runoff into streams (Barling and Moore 1994; Roberts et al. 2012). However, attributes of riparian land use types, hydrogeomorphic conditions, and vegetation and human activities have substantial impact on the fate and transport of solutes through riparian zones (Krause et al. 2008; Merritt et al. 2009). To take appropriate measures to minimize the input of agricultural chemicals into surface waters, detailed knowledge is required about all the factors controlling the loss of pesticides from riparian zones within a whole basin. Identification of areas at risk for loss of agricultural chemicals is a necessary requirement for targeting the best management practices (BMPs) to the most vulnerable areas. At the field or small catchment scale, many studies have been carried out to examine the effectiveness of different riparian buffer types in reducing sediment, nutrient, and herbicide loads into surface and groundwater in agricultural catchments (Zhao et al. 2009; Bicalho et al. 2010; Weller et al. 2011). However, few studies have been carried out to evaluate the performance of different riparian land use types in reducing herbicide loads and transporting risk at a whole basin scale.

Agriculture dominates most of the landscape in riparian zones of the Songhua River Basin, northeastern China. Farming practices including tilling and harvesting could expose bare soils which are highly susceptible to erosion. And agricultural chemicals, such as herbicides and nutrients, could be dispersed into water bodies by diverse mechanisms like runoff, leaching, and drainage from agricultural fields ( $\mathrm{Ng}$ and Clegg 1997; Hancock et al. 2008). Agricultural chemicals rank as the top water quality impairment in the Songhua River Basin (Zhou et al. 2008).

In this work, we investigated the pattern of riparian land use and the residues of commonly used herbicides in riparian soils and soil columns of different land use types in the Songhua River Basin. These data can provide insight into the occurrence and distribution of herbicides in riparian zones of the whole basin. In particular, we discussed about (1) the impact of riparian land use on herbicide residues into soils considering both surface samples and columnar samples and (2) the spatial distribution of herbicide contamination in riparian zones and risk assessment of herbicide transport to rivers in the basin based on soil erosion and herbicide residues. Therefore, this study contributes to give some information to land managers so as to identify the cultivated areas of riparian zones that should be partly converted into forestry or grass to decrease the contamination and target the placement of BMPs to riparian areas in the basin that are most vulnerable to herbicide transport.

\section{Materials and methods}

\subsection{Study area}

The Songhua River is the biggest river in northeastern China and flows about 1,927 km from the Changbai Mountain and 
the Greater Khingan Mountain through Heilongjiang Province, Inner Mongolia Autonomous Region and Jilin Province (Fig. 2). The Songhua River Basin drains $557,000 \mathrm{~m}^{2}$ of land, which is an important base of commodity grain production in China. As one of the intensive agricultural basin, various pesticides, especially herbicides have been increasingly applied in recent years. Furthermore, because the basin has a long cold winter, windy dry spring, and rainy summer, herbicides applied in spring are much easily adsorbed to soil and vulnerable to be lost with soil erosion in summer.

\subsection{Data collection and monitoring}

The sampling sites were selected by a $20-\mathrm{km}$ interval along the Songhua River in the map using Arcmap-ArcGIS 9.3.1 firstly, and a slight adjustment was done in field survey based on the attributes of watershed such as the geomorphology of the main channel of rivers, the hydrological regime, the localization of urban and industrial discharges, and the land use types of riversides. Sampling sites along the Songhua River and its major tributaries were displayed in Fig. 2. All sampling and pretreatment of samples follow the Chinese National Standards for Scientific Sampling (Chinese
State Environmental Protection Administration 2002). The soil samples were obtained from surface soils $(0 \sim 20 \mathrm{~cm})$ of main land use type in riparian zones from corresponding sites. Three parallel samples of soils were collected and homogenized in each site, and stored in $0 \sim 4{ }^{\circ} \mathrm{C}$ by portable fridge. All samples were quickly carried back to a laboratory and stored in a $-20{ }^{\circ} \mathrm{C}$ fridge before analysis. Column samples were obtained by a soil columnar sampler (XDB0302, New Landmark Soil Equipment Co., Ltd., Beijing, China) around site 18 in the Sanjiang Plain (Fig. 2). The Sanjiang Plain is an important agricultural region in China, which is famous for its vast and fertile black soil in the world. Because of its homogenous topography, soil type, and tillage management, the main factor impacting transport of herbicides in riparian zones might be the land use type in these areas. Therefore, we selected a typical reach (around site 18) in the Sanjiang Plain under cultivation and cultivation with the grass buffer in riparian zones to obtain column soil samples. The bare land was aside the farmland without the grass buffer. Farmland and grassland soil samples were gotten from the corresponding land use types. All sampling sites were numbered and referenced using a global positioning system (Fig. 2). The main land use types and crop types in sampling sites were recorded. All samples were collected

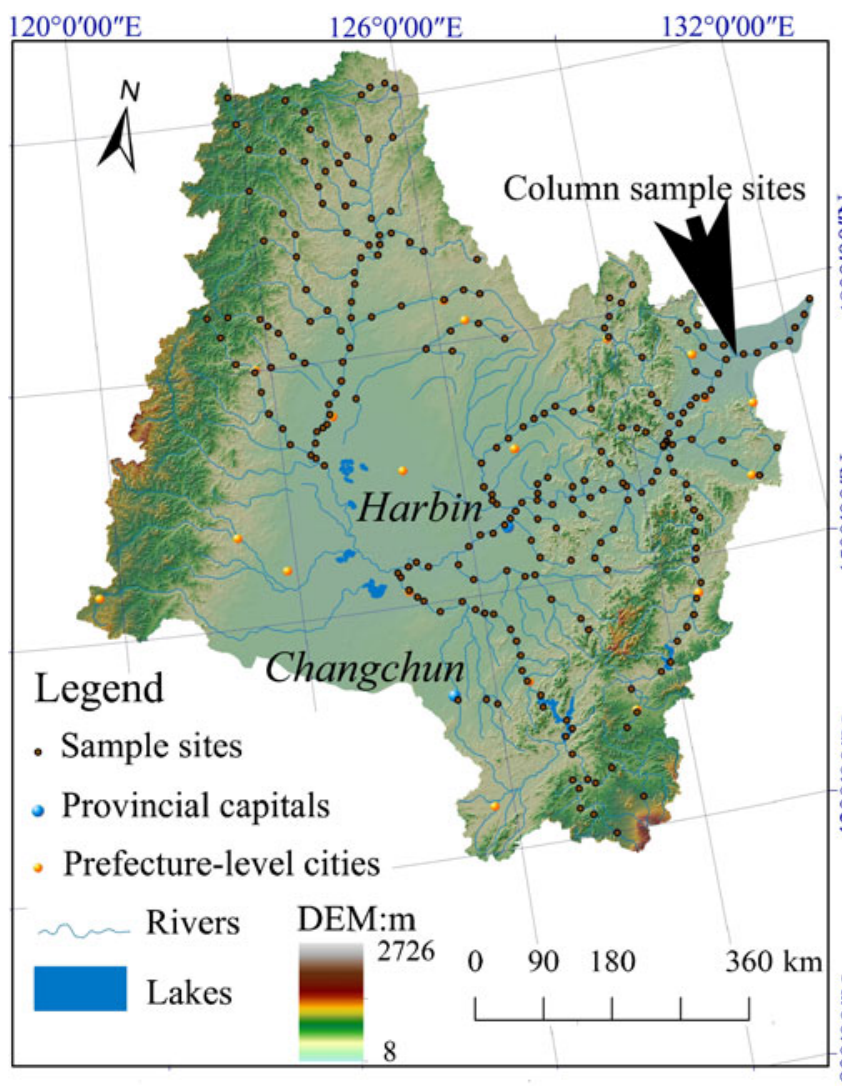

Fig. 2 Sampling sites and distribution of herbicide residues in riparian soil of the Songhua River Basin. The topography is displayed in color from light to deep which is the important factor impact to soil erosion

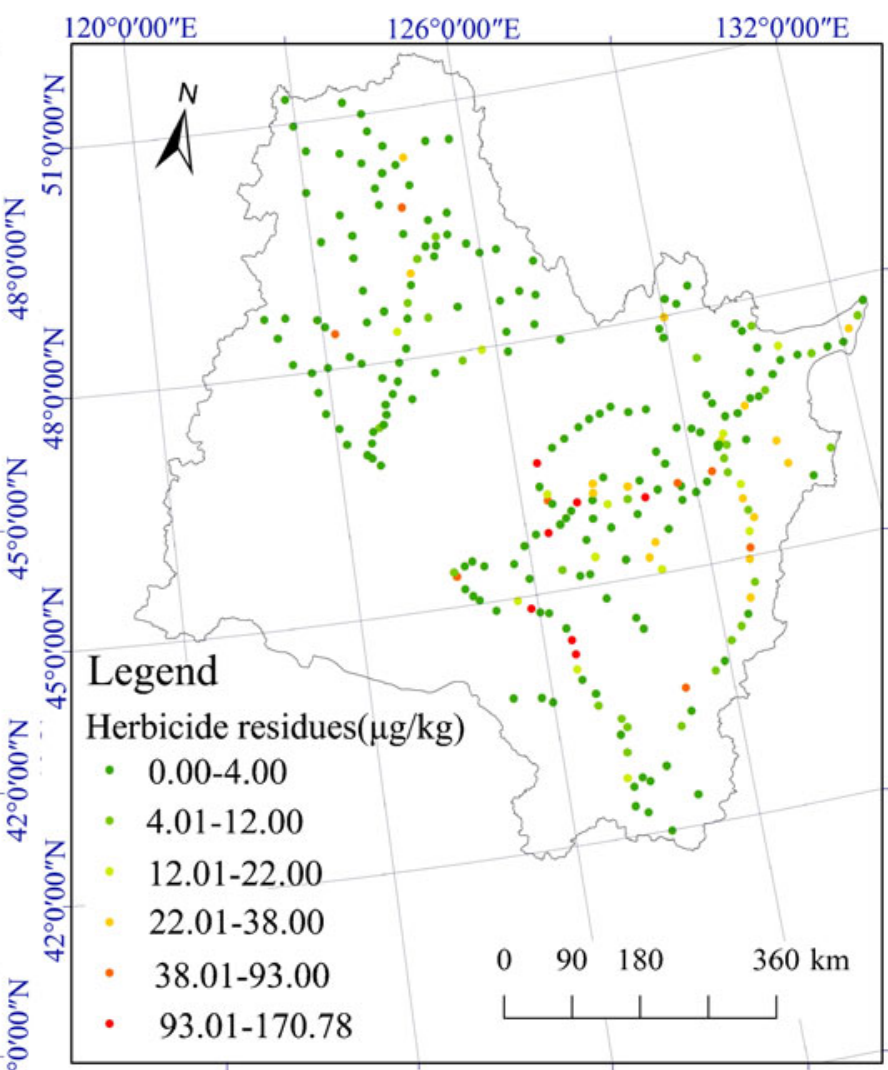

and herbicide transport. Yellow and blue points are delegated provincial capitals and prefecture cities. Red points represent sampling sites. The colors from blue to red display the herbicide levels 
from June to August in 2010. The 189 soil samples were collected from 248 riparian sites in the Songhua River Basin, and 59 sites had no soil samples because of concrete or rocky bank.

Soil samples were freeze dried in a vacuum freeze dryer (FD1; Boyikang Experiment Instrument Ltd, Beijing, China). Pieces of stones and plants were removed. Samples were ground, passed through a $0.15-\mathrm{mm}$ sieve, and stored in brown glass jars at $-20{ }^{\circ} \mathrm{C}$ before use. The samples were extracted by solvents using an ultrasonic oscillator according to the Standards Method for Liaoning Province (Inspection and Testing Center for Agro-Product Safety and Environmental Quality 2002). Twenty grams was weighted into a glass vial and sonicated for $30 \mathrm{~min}$ with $40 \mathrm{ml}$ of acetone $/ n$-hexane (4:1, $v / v)$ in an ultrasonic bath (KQ250B, Kunshan Ultrasonic Bath Plant, China). The extraction processes were repeated twice and the suspension were centrifuged. Extracts were transferred into glass flasks by careful decantation. The extracts were evaporated under vacuum with a rotavapor (EYEL4 rotary vacuum evaporator N-N series, Tokyo, Japan) in water bath (about $35^{\circ} \mathrm{C}$ ). The residues were cleaned up by a column $(8 \mathrm{~mm}$ i.d. $\times 150 \mathrm{~mm})$ containing $0.5 \mathrm{~g}$ of Florisil and $0.5 \mathrm{~g}$ neutral alumina. Anhydrous sodium sulfate $(1 \mathrm{~cm})$ was added to the top and bottom of the column in order to remove water. The column was then eluted firstly with $8 \mathrm{ml}$ of acetone $/ n$-hexane $(2 / 98, v / v)$ and the solution was discarded. Another $25 \mathrm{ml}$ of acetone $/ n$-hexane $(4 / 96, v / v)$ was needed for elution to obtain acetochlor. After collection, the eluant was evaporated near dryness under a nitrogen flow. Subsequently, the sample was dissolved in $1 \mathrm{ml}$ of $n$-hexane for gas chromatography (GC) determination.

The widely used herbicides, including acetochlor and atrazine, were detected in this study. Atrazine and acetochlor concentration was determined by a GC system with a microcell electron capture detector and split/splitless injector (Agilent Series 6890 plus), equipped with the ChemStation Software. A fused silica capillary column (HP-5, $30 \mathrm{~m} \times 0.25 \mathrm{~mm}$ i.d. and $0.25 \mu \mathrm{m}$ film thickness) was used. The oven temperature was programmed from 60 to $150{ }^{\circ} \mathrm{C}$ at a rate of $20^{\circ} \mathrm{C} \mathrm{min}^{-1}$, then from 150 to $230^{\circ} \mathrm{C}$ at a rate of $8{ }^{\circ} \mathrm{C} \mathrm{min}^{-1}$ and held for $5.5 \mathrm{~min}$. The retention times of atrazine and acetochlor were 8.104 and $9.369 \mathrm{~min}$, respectively. Nitrogen (99\%) was used as the carrier gas and make up the gas. A split/splitless was used in the splitless mode. The temperature of the injector and the electron capture detector was set at 220 and $300{ }^{\circ} \mathrm{C}$, respectively. The injection volume was $1 \mu$. The recovery of atrazine and acetochlor was 70.2 95.4 and 70.2 98.3\%, respectively, and RSD was 3.4 7.2 and 3.0 7.1\%, respectively. The detection limit of atrazine and acetochlor was both $0.01 \mu \mathrm{g} / \mathrm{kg}$. The recovery was satisfactory for atrazine and acetochlor and it was corrected for quantification. Total organic carbon (TOC) of soils was detected by the Vario EL III elemental analyzer (Elementar, Germany).

\subsection{Data analyses}

The spatial distribution analyses of herbicides in the Songhua River Basin were performed based on the map of rivers and cities in the Songhua River Basin at 1:250,000 scale using ESRI ArcGIS 9.3.1 (ESRI 2009). In order to assess the risk of herbicide transport in riparian zones, we overlapped the map layers of spatial distribution of herbicide residues and soil erosion intensity of riparian zones. The map of soil erosion intensity $(1: 100,000$ scale) in riparian zones was obtained from the Chinese Research Academy of Environmental Sciences. In the map of soil erosion intensity, the soil of the basin was eroded by water and wind mainly and the intensity of soil erosion was classified into six grades: $<200,200-2,500$, $2,500-5,000,5,000-8,000,8,000-15,000$, and $>15,000 \mathrm{t} /\left(\mathrm{km}^{2} \cdot \mathrm{a}\right)$ (the classification criterion of soil erosion of China, SL190-96; Fig. 3). Since the data of herbicide residues in riparian zones consist of individual sites across rather than a continuous map surface, which could not assess herbicide-transporting risk through raster calculation with the layer of soil erosion intensity, the forecast map of herbicide residues in soils was generated by herbicide residues in sampling sites using the interpolation of the kriging geostatistical analyst by ArcMap 9.3.1. Interpolation by kriging is a geostatistical method based on statistical models that predict spatial autocorrelation of sampled data sites, as the most accurate prediction map due to the spatial autocorrelation introduced by this geostatistical model (Isaaks and Srivastava 1989). Normal QQPlot-Geostatistical Analyst (ArcMap 9.3.1) was used to examine the distribution of herbicide residues in riparian zones before interpolation. The result displayed that the data were normally distributed after logarithmic transformation. The prediction map layer was created by logarithmic transformation and the kriging method on the basis of the distribution map of herbicide residues in riparian farmland soils. Using the raster calculator of spatial analyst of ArcGIS, risk assessment of herbicide transport was analyzed based on the forecast map layer of herbicide residues and the layer of soil erosion intensity. Considering integrated ecological function of riparian buffer zones and other analogous study (Pert et al. 2010), the study defined a buffer width of $200 \mathrm{~m}$ at each side of the main streams including the Nenjiang River, the Second Songhua River, and the Songhua River, and important tributaries were given $100 \mathrm{~m}$ at each side. The "buffer" command was used to create the riparian zones around the streams and rivers by ArcMap 9.3.1. Finally, the map layer of risk assessment was clipped by the layer of riparian buffer zones. In order to give explicit target of conservation to land managers, the map of risk assessment of riparian herbicide transport was performed by the command of "Zonal Statistics" based on county using ArcMap 9.3.1 (Fig. 3).

Statistical analyses were performed using SPSS 19.0 (SPSS Inc., Chicago, IL, USA) and all graphics were 


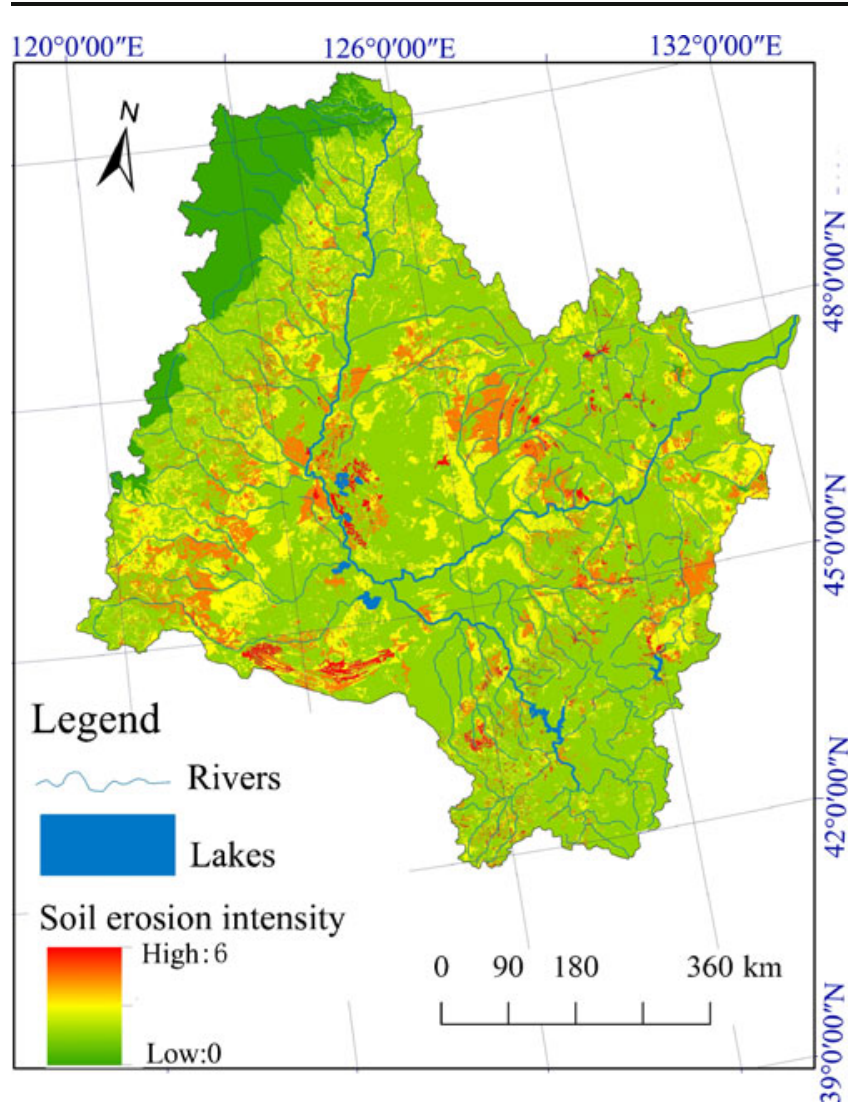

Fig. 3 The soil erosion intensity and herbicide transporting risk in riparian zones of the Songhua River Basin. The colors from blue to red reflect the intensity of soil erosion (left) and display the

drawn by Origin 8.5 . In analyses of the factor tested and compared, $P<0.05$ indicated statistical significance. The Pearson correlation analysis between the TOC and the concentration of herbicides was analyzed by the two-tailed test.

\section{Results and discussion}

\subsection{Occurrence of herbicides in riparian soils}

The percentage of farmland, grassland, forest land, and bare land in sample sites was $35.4,29.6,6.2$, and $28.8 \%$, respectively. The Songhua River Basin has imported large amounts of herbicides in order to control and eliminate weeds ( $\mathrm{Su}$ 2004). These compounds have been applied directly to the soil and sprayed over cultivated areas, which has led to residues throughout the riparian zones in the whole basin confirmed by our study. According to the results of investigation, the detection ratio of herbicides in soils was $97.37 \%$ in the riparian zones of Songhua River Basin. However, atrazine was not as widely detected in riparian soils as acetochlor from our investigation, but the correlation $120^{\circ} 0^{\prime} 00^{\prime \prime} \mathrm{E}$ $126^{\circ} 0^{\prime} 00^{\prime \prime} \mathrm{E}$ $132^{\circ} 0^{\prime} 00^{\prime \prime} \mathrm{E}$

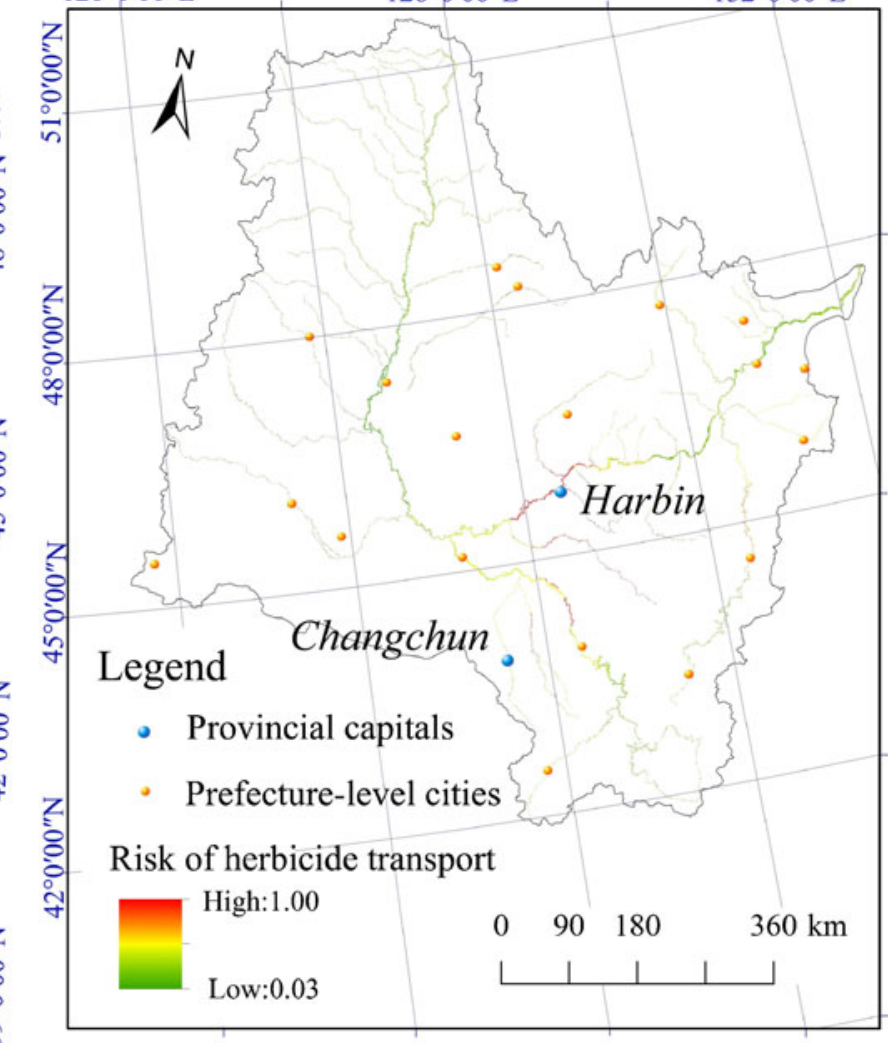

risk of herbicide transport (right) of riparian zones to each county in the basin. The colors from blue to red of right map reflect the degree of risk

coefficient between residues of acetochlor and atrazine in soils was significant $(P=0.037,<0.05)$, which suggested that atrazine might be always applied with acetochlor in farmland. Our results are corroborated by Wang et al. who investigated the residue of herbicides in agricultural soils in Liaoning Province in northeastern China and indicated that the correlation between residues of acetochlor and atrazine was significant (Wang et al. 2010), which agree with our study.

In general, because of its higher detection ratio and residue level, the contamination of herbicides in riparian soils of the Songhua River Basin was more serious than other areas of China. The average concentration of acetochlor in farmland soils was $26.10 \mu \mathrm{g} / \mathrm{kg}$, excluding the sample from site 16 where the concentration was up to $709.37 \mu \mathrm{g} / \mathrm{kg}$, and the average concentration of atrazine was $11.28 \mu \mathrm{g} / \mathrm{kg}$ (Table 1). A research on the agricultural soils of Liaoning Province in northeastern China indicated that the average residual concentration of acetochlor and atrazine in agricultural soils was 25.83 $(0.53 \sim 203.20)$ and $4.24(0.14 \sim 21.20) \mu \mathrm{g} / \mathrm{kg}$, respectively (Wang et al. 2010). Thus, the residual levels of most part of riparian agriculture soils in the Songhua River Basin were higher than in these areas. 
Table 1 The concentration of herbicides and TOC in riparian soils $(0-20 \mathrm{~cm})$ for each land use type

\begin{tabular}{|c|c|c|c|c|}
\hline & Farmland & Grassland & Forest land & Bare land \\
\hline Percentage of each land use type & $34.4 \%$ & $36.4 \%$ & $10.5 \%$ & $18.6 \%$ \\
\hline $\begin{array}{l}\text { Average concentration } \\
\text { of acetochlor }(\mu \mathrm{g} / \mathrm{kg})\end{array}$ & $26.10(0.23-170.78)$ & $1.76(0.05-7.89)$ & $1.46(0.14-3.61)$ & $2.48(0.59-9.3)$ \\
\hline $\begin{array}{l}\text { Average concentration } \\
\text { of atrazine }(\mu \mathrm{g} / \mathrm{kg})\end{array}$ & $11.28(0.42-52.96)$ & $0.51(0.1-1.08)$ & - & $0.13(0.13)$ \\
\hline TOC $(\mathrm{g} / \mathrm{kg})$ & $14.50(5.11-35.01)$ & $13.93(4.37-28.99)$ & $13.72(5.49-37.84)$ & $10.53(3.64-17.64)$ \\
\hline $\begin{array}{l}\text { Correlation coefficient } \\
\text { between acetochlor } \\
\text { 'residues and TOC }\end{array}$ & $\begin{array}{l}-0.049 \\
\quad(P=0.676,>0.01)\end{array}$ & $\begin{array}{l}0.277^{\mathrm{a}} \\
\quad(P=0.023,<0.05)\end{array}$ & $\begin{array}{l}0.528^{\mathrm{a}} \\
\quad(P=0.043,<0.05)\end{array}$ & $\begin{array}{l}-0.244 \\
\quad(P=0.344,>0.01)\end{array}$ \\
\hline
\end{tabular}

The table displays the concentration of herbicides and TOC in riparian soils $(0-20 \mathrm{~cm})$ of each land use type. The correlations between TOC and herbicide residues in each land use types are analyzed

TOC total organic carbon

${ }^{a}$ Correlation is significant at the 0.05 level (two tailed)

3.2 Impact of riparian land use type on herbicide residues in soils

Cultivated land accounts for the largest proportion in riparian zones of the Songhua River Basin from our investigation, up to $35.4 \%$. Furthermore, the percentage of maize and soybean was $87.5 \%$ of farmland sites, and the crops growing in the other sites were wheat, ground cherry, Chinese cabbage, and pumpkin (Table 2). The average residues of acetochlor in farmland soils of maize and soybean land were 54.76 and $24.33 \mu \mathrm{g} / \mathrm{kg}$, respectively. And the average residues of atrazine were 13.55 and $7.80 \mu \mathrm{g} / \mathrm{kg}$, respectively (Table 2). The residual level of acetochlor in soil of ground cherry and pumpkin land was 16.34 and 13.35 , respectively. The herbicide residues in farmland soils are associated with herbicide application and crop types. Acetochlor and atrazine were applied in maize and soybean land mainly in the basin. And the proportion of cultivated areas of maize and soybean in the Songhua River Basin was above $80 \%$. In any

Table 2 The concentration of herbicides in riparian farmland soils $(0-20 \mathrm{~cm})$

\begin{tabular}{lll}
\hline & \multicolumn{2}{l}{ Average residues of herbicide in farmland } \\
\cline { 2 - 3 } & Acetochlor & Atrazine \\
\hline Maize & $54.76(0.26-170.78)$ & $13.55(2.84-52.96)$ \\
Soybean & $24.33(0.23-50.23)$ & $7.80(0.42-34.42)$ \\
Pumpkin & $13.35(10.44-12.26)$ & - \\
Unplanted farmland & $15.40(1.04-32.98)$ & - \\
Ground cherry & $16.34(16.34)$ & - \\
Chinese cabbage & $2.18(0.35-4.61)$ & - \\
Wheat & $0.87(0.87)$ & - \\
\hline
\end{tabular}

The table provides the information on herbicide residues of each crop type of farmland soils, which suggests the amount of herbicide application in different farmland case, the detection ratio of herbicides in riparian farmland was $100 \%$, and rivers in the basin were vulnerable to herbicide pollution because of riparian cultivation.

The residues of herbicides in soils of other land use types were lower than in farmland (Table 1). Moreover, the related coefficients between herbicide residues and TOC in different land use types were not the same. The correlations between herbicide residues and TOC in soils of farmland and bare land were not significant, but the correlation coefficients between acetochlor residues and TOC of grassland and forestland were significant, up to $0.277(P=0.023$, $<0.05)$ and $0.528(P=0.043,<0.05)$, respectively. Many factors impacted the residual level of herbicides in riparian farmland, such as application amount, agricultural practices, soil erosion, and soil physicochemical properties. On the other side, agricultural practices could change the content of total organic matter. These were the reason to the nonsignificant correlations between herbicide residues and TOC in soils of farmland. However, the loss of organic matter and herbicides from bare land was higher than that from grassland and forestland because of soil erosion, and it might be the main reason of correlation difference of land use types. Our investigation suggested that herbicide residues were detected in $94.4 \%$ of bare land soils, which might be originated from adjacent agricultural soils. It was at high risk of transport to the reaches with bare land riparian bank, and $28.8 \%$ of sampling sites were bare land in our investigation. The average residual level of acetochlor was higher than that of grassland and forestland (Table 1); therefore, the reaches with bare land riparian bank were more vulnerable to transportation of herbicides and other pollutants, especially in a rainy season.

Previous studies have shown improved soil physical properties of vegetated riparian buffers relative to adjacent croplands, such as greater saturated hydraulic conductivity, macro- and mesoporosity, water storage capacity, aggregate 

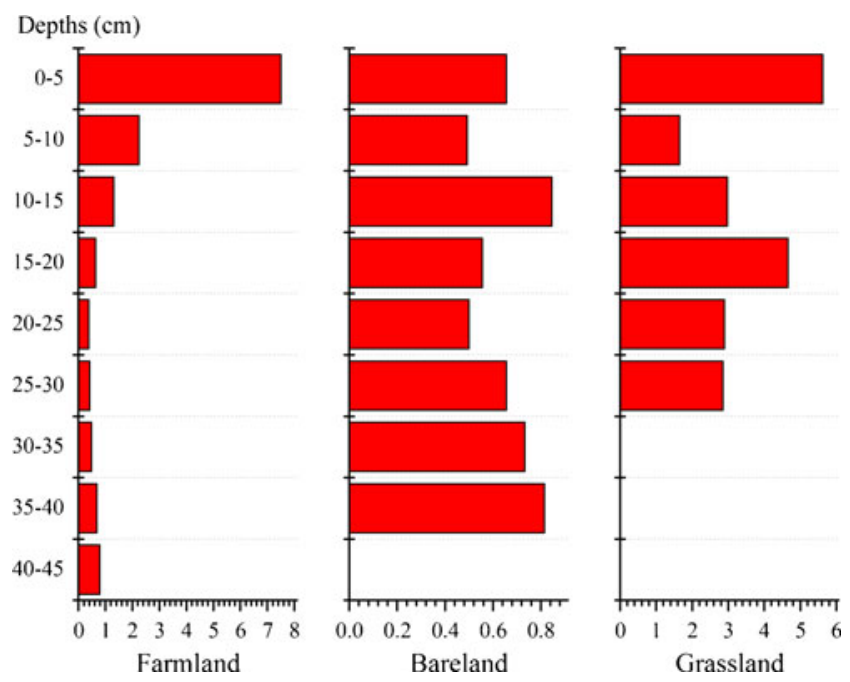

Fig. 4 Vertical distributions of herbicide residues in riparian soils. The picture displays vertical distributions of acetochlor residues of the three-columned samples, which suggests the different herbicide transport of land use types

stability, and lower bulk density (Seobi et al. 2005; Udawatta et al. 2008a, b). Additionally, the content of soil organic carbon has been observed to be increased in agroforestry and grass buffers compared to cropland soils, which could enhance sorption properties of agrochemicals (Udawatta et al. 2009; Chu et al. 2010). Thus, vegetated riparian zones can help to remove herbicides by decreasing runoff velocity and increasing their retention by soil. Coupling our results with previous studies suggested that grassland and forestland of riparian zones in the Songhua River
Basin could retain leached herbicides into the soils and acted as vegetated riparian buffers.

Furthermore, vertical distribution trends of herbicides in riparian soils also suggested transport or retention of herbicides in soils of different land use types (Fig. 4). Three columnar samples were collected in riparian soils in the Sanjiang Plain, which was the most important agricultural area in the downstream of the Songhua River. Atrazine was not detected in these samples. Vertical distribution trend of acetochlor concentrations in farmland soil indicated that the residues of acetochlor declined from 0 to $25 \mathrm{~cm}$ depth of soil and could leach below $25 \mathrm{~cm}$. These trends suggested that the cultivation layer was above $25 \mathrm{~cm}$ depth of soils and herbicides in farmland could migrate slightly with a long time of application below cultivation layer though leaching. The vertical distribution trend in agricultural soils suggested herbicide accumulation in soils below $25 \mathrm{~cm}$, but the results of vertical distribution of acetochlor concentrations in the riparian soils of grassland and bare land did not display similar patterns (Fig. 4). The concentration of acetochlor in surface layer $(0 \sim 5 \mathrm{~cm}$ depths) of grassland soils was significantly more than that in lower layer of soil and accumulated from 5 to $20 \mathrm{~cm}$ depths of soils (Fig. 4), which might suggest herbicide retention in vegetated riparian zones compared to bare land and farmland. The residue level of acetochlor in riparian bare land was much lower than that in farm land and grassland, and the vertical distribution trend was not regular. As suggested above, these soils are not likely to infiltrate water and are rather submitted to runoff and soil erosion.

Table 3 The use of pesticides in Heilongjiang Province

\begin{tabular}{|c|c|c|c|c|c|}
\hline $\begin{array}{l}\text { Prefecture-level } \\
\text { city }\end{array}$ & Pesticide purchases (ton) & Sown areas (ha) & Pesticides using density ( $\mathrm{kg} / \mathrm{ha})$ & $\begin{array}{l}\text { Measured } \\
\text { residues } \\
(\mu \mathrm{g} / \mathrm{kg})\end{array}$ & $\begin{array}{l}\text { Predicted } \\
\text { residues } \\
(\mu \mathrm{g} / \mathrm{kg})\end{array}$ \\
\hline Yichun & 932.2 & 198,522 & 4.70 & 26.25 & 19.35 \\
\hline Shuihua & $6,405.7$ & $1,648,955$ & 3.88 & 42.30 & 32.69 \\
\hline Shuangyashan & $1,286.1$ & 374,752 & 3.43 & - & 27.16 \\
\hline Qiqihaer & $4,776.9$ & $2,084,784$ & 2.29 & 4.82 & 11.12 \\
\hline Qitaihe & 623.3 & 151,388 & 4.12 & - & 40.87 \\
\hline Mudanjiang & $2,572.7$ & 474,784 & 5.42 & 20.39 & 27.98 \\
\hline Jiamusi & $3,533.0$ & $1,073,832$ & 3.29 & 14.04 & 27.31 \\
\hline Jixi & $1,772.7$ & 398,727 & 4.45 & - & 45.60 \\
\hline Heihe & $2,122.1$ & 817,421 & 2.60 & 3.15 & 16.07 \\
\hline Hegang & 570.0 & 168,595 & 3.38 & 18.33 & 19.39 \\
\hline Harbin & $8,133.3$ & $1,799,273$ & 4.52 & 35.81 & 53.69 \\
\hline Daxinganlin & 413.7 & 96,841 & 4.27 & - & - \\
\hline Daqing & $1,868.8$ & 620,806 & 3.01 & - & 23.23 \\
\hline
\end{tabular}

The data on pesticide purchases and sown areas come from the statistical yearbook of Heilongjiang province in 2011. The table provides the information on pesticide application of each prefecture-level city, which suggests the relation between pesticide application and herbicide residues of farmland 
3.3 Risk assessment of herbicide transportation and pollution to water bodies in the basin

There are many factors affecting herbicide transport to streams, such as soil and hydrologic properties and geomorphologic characteristics of the watershed, land use and herbicide management, climate factors, including precipitation and temperature, and chemical and physical properties and formulation of herbicides (Lerch and Blanchard 2003). In this study, we considered the following factors: hydrogeomorphic setting, land use of riparian zones, and the load of herbicides in the Songhua River Basin. Ma (2009) investigated the structure of pesticide applications in Heilongjiang Province and the result displayed that the annual application of herbicides accounted for $76.4 \sim 83.4 \%$ of the total pesticides applied, and the kind of herbicides applied to dry farmland was over $70 \%$ of the total herbicides, especially. Furthermore, over $70 \%$ of herbicides were sprayed directly into the surface of soil (Su 2004; Ma 2009). Acetochlor or mixture of acetochlor and atrazine represents these herbicides. Maize and soybean were the main dry land crops in the Songhua River Basin. Therefore, the method of herbicide application in most areas of this basin was similar, and the loading of herbicides could be reflected by the residual level of herbicides in farmland soils. Since 76.4 83.4\% of the total pesticide application was the herbicide, Spearman's rho correlation coefficient between pesticides using the density and herbicide residues of riparian farmland soils in Heilongjiang Province was $0.74(P=0.037,<0.05$; Table 3$)$, which suggested the result above. In this view, total herbicide residues in soils for the whole studied zone could be estimated from herbicide application. Using the kriging interpolation of geostatistical analyst of ArcGIS 9.3.1, the forecast distribution map of herbicide residues in farmland was generated by herbicide residues of farmland sampling sites. The forecast value also significantly correlated with pesticides using the density of each area (Table 3).

Hydrogeomorphic setting and land use types of riparian zones impacted herbicide transport by the means of soil erosion mainly. In our study, soil erosion intensity dataset was used as a synthetic factor to reflect climate factors, hydrogeomorphic setting, and land use types of riparian zones, which came from remote sensing images and field investigation. The dataset of soil erosion intensity was multiplied by the forecast map of herbicide residues in riparian zones by a raster calculator of ArcGIS 9.3.1 and generated the risk map of riparian herbicide transport in the whole basin (Fig. 3). From the result of risk assessment of herbicide transport, the middle reaches of the Songhua River were seriously polluted areas from the distribution map of herbicide residues (Fig. 2). The Qitaihe, Mudanjiang, and part of the areas on the upstream of the Nenjiang River were also seriously contaminated areas (Fig. 2), but the risk of these areas was not in the front rank because of riparian vegetation zones.

\section{Conclusion}

We sampled riparian soils in the Songhua River Basin and analyzed for herbicides including atrazine and acetochlor before the rainy season. The concentration and detection ratio of herbicides in soils suggested the fact that there were wide and serious herbicide residues throughout riparian zones of the whole basin. The risk of herbicide transportation in middle reaches of the Songhua River was the highest than other reaches because of land use and herbicide application. To land use of grassland and forestland in riparian zones of this basin, they acted as a physical barrier for herbicide retention which was proved indirectly by the relation of herbicide residues and TOC in soils and the vertical trend of herbicide residues in the soil profile. And our results also indicated that farmland and bare land were more vulnerable to soil erosion and herbicide transportation. Since the spatial pattern of herbicide application and transport is heterogeneous, the contributions of different riparian land use to the herbicide load in the streams may differ considerably within whole basin. Therefore, the assessment of herbicide transporting risk could help to target mitigation measures efficiently to those locations where they reduce herbicide pollution mostly. Management practices to improve water quality must be designed in accordance with the dominant problems of the basin.

Acknowledgments This work was financially supported by the National Natural Science Foundation as a key project (grant no. 21037002) and by the National Special Water Project in China (grant no. 2012ZX07501002-001). We thank our sampling assistants from the Agriculture University of Northeast China namely Qingjuan Meng, Yingjie Dai, and Huosheng Guo from the Agriculture University of Northeast China and Tao Hua, Wenlu Zeng, Fengxiang Li, Yao Liu, Zhineng Zhang, etc. from Nankai University.

\section{References}

Barling RD, Moore ID (1994) Role of buffer strips in management of waterway pollution: a review. Environ Manag 18(4):543-558. doi:10.1007/BF02400858

Bicalho STT, Langenbach T, Rodrigues RR, Correia FV, Hagler AN, Matallo MB, Luchini LC (2010) Herbicide distribution in soils of a riparian forest and neighboring sugar cane field. Geoderma 158(3-4):392-397. doi:10.1016/j.geoderma.2010.06.008

Chinese State Environmental Protection Administration (2002) The monitoring and analysis methods of water and waste water. Environmental Science Press in China, Beijing

Chu B, Goyne KW, Anderson SH, Lin CH, Udawatta RP (2010) Veterinary antibiotic sorption to agroforestry buffer, grass buffer and cropland soils. Agron Syst 79(1):67-80. doi:10.1007/s10457009-9273-3

ESRI (Environmental Systems Research Institute) (2009) ArcGIS 9.3.1. Environmental Systems Research Institute, Redlands, California, USA 
Guo D (2005) Impact of the Yellow River on change of land-use pattern in recent Yellow River delta. J Agro Environ Sci 24 (4):757-760

Hancock TC, Sandstrom MW, Vogel JR, Webb RMT, Bayless ER, Barbash JE (2008) Pesticide fate and transport throughout unsaturated zones in five agricultural settings, USA. J Environ Qual 37(3):1086-1100. doi:10.2134/jeq2007.0024

Huang K, Guo H, Liu Y, Yu Y, Zhou F (2007) Research progress on the degradation mechanisms and restoration of riparian ecosystem. Chin J Appl Ecol 18(6):1373-1382

Inspection and Testing Center for Agro-Product Safety and Environmental Quality, Chinese Academy of Science (CAS) (2002) Detection of acetochlor and butachlor residues in soil. Agriculture Commission of Liaoning province

Isaaks EH, Srivastava RM (1989) An introduction to applied geostatistics. Oxford University Press, Oxford

Krause S, Jacobs J, Voss A, Bronstert A, Zehe E (2008) Assessing the impact of changes in land use and management practices on the diffuse pollution and retention of nitrate in a riparian floodplain. Sci Total Environ 389(1):149-164. doi:10.1016/j.scitotenv.2007.08.057

Lerch R, Blanchard P (2003) Watershed vulnerability to herbicide transport in northern Missouri and southern Iowa streams. Environ Sci Technol 37(24):5518-5527. doi:10.1021/es030431s

Ma J (2009) Research on structure of pesticides applications in Heilongjiang Province. Pestic Sci Admin 30(2):55-56

Merritt DM, Scott ML, Leroy P, Auble GT, Lytle DA (2009) Theory, methods and tools for determining environmental flows for riparian vegetation: riparian vegetation-flow response guilds. Freshw Biol 55(1):206-225. doi:10.1111/j.1365-2427.2009.02206.x

Naiman RJ, Décamps H (1997) The ecology of interfaces: riparian zones. Ann Rev Eco Syst 28:621-658

Naiman RJ, Decamps H, Pollock M (1993) The role of riparian corridors in maintaining regional biodiversity. Ecol Appl 3 (2):209-212. doi:10.2307/1941822

Ng HYF, Clegg SB (1997) Atrazine and metolachlor losses in runoff events from an agricultural watershed: the importance of runoff components. Sci Total Environ 193(3):215-228. doi:10.1016/ S0048-9697(96)05342-9

Pert PL, Butler JRA, Brodie JE, Bruce C, Honzák M, Kroon FJ, Metcalfe D, Mitchell D, Wong G (2010) A catchment-based approach to mapping hydrological ecosystem services using riparian habitat: a case study from the Wet Tropics, Australia. Ecol Complex 7(3):378-388. doi:10.1016/j.ecocom.2010.05.002

Roberts WM, Stutter MI, Haygarth PM (2012) Phosphorus retention and remobilization in vegetated buffer strips: a review. J Environ Qual 41(2):389-399. doi:10.2134/jeq2010.0543
Seobi T, Anderson S, Udawatta R, Gantzer C (2005) Influence of grass and agroforestry buffer strips on soil hydraulic properties for an Albaqualf. Soil Sci Soc Am J 69(3):893-901. doi:10.2136/ sssaj2004.0280

Su S (2004) Problems with herbicide use in northeast China. Chin J Pestic 43(2):53-55

Tomer MD, Dosskey MG, Burkart MR, James DE, Helmers MJ, Eisenhauer DE (2009) Methods to prioritize placement of riparian buffers for improved water quality. Agrofor Syst 75(1):17-25. doi:10.1007/s10457-008-9134-5

Udawatta RP, Gantzer CJ, Anderson SH, Garrett HE (2008a) Agroforestry and grass buffer effects on pore characteristics measured by high-resolution X-ray computed tomography. Soil Sci Soc Am J 72(2):295-304. doi:10.2136/sssaj2007.0057

Udawatta RP, Kremer RJ, Adamson BW, Anderson SH (2008b) Variations in soil aggregate stability and enzyme activities in a temperate agroforestry practice. Appl Soil Ecol 39(2):153-160. doi:10.1016/j.apsoil.2007.12.002

Udawatta RP, Kremer RJ, Garrett HE, Anderson SH (2009) Soil enzyme activities and physical properties in a watershed managed under agroforestry and row-crop systems. Agric Ecosyst Environ 131(1):98-104. doi:10.1016/j.agee.2008.06.001

Vidon P, Allan C, Burns D, Duval TP, Gurwick N, Inamdar S, Lowrance R, Okay J, Scott D, Sebestyen S (2010) Hot spots and hot moments in riparian zones: potential for improved water quality management. J Am Water Resour Assoc 46(2):278-298. doi:10.1111/j.1752-1688.2010.00420.x

Wang W, Wang Y, Wang S, Wang S, Li G (2010) Residual characteristics of herbicides and organochlorine pesticides in agricultural soils in northern Liaoning Province. Chin J Soil Sci 41(3):716-722

Weller DE, Baker ME, Jordan TE (2011) Effects of riparian buffers on nitrate concentrations in watershed discharges: new models and management implications. Ecol Appl 21(5):1679-1695. doi:10.1890/10-0789.1

Zhao T, Xu H, He Y, Tai C, Meng H, Zeng F, Xing M (2009) Agricultural non-point nitrogen pollution control function of different vegetation types in riparian wetlands: a case study in the Yellow River wetland in China. J Environ Sci 21:933-939. doi:10.1016/S1001-0742(08)62364-5

Zhou Q (2005) Health soil science: soil health quality and safety of agricultural products. Science Press, Beijing

Zhou Q, Luo Y (2011) Pollution eco-chemistry. Science Press, Beijing

Zhou Q, Wang M, Liang J (2008) Ecological detoxification of methamidophos by earthworms in phaiozem co-contaminated with acetochlor and copper. Appl Soil Ecol 40(1):138-145. doi:10.1016/j.apsoil.2008.03.014 